\title{
Simple and cost-effective laboratory methods to evaluate and validate cell-free DNA isolation
}

\author{
Afsaneh Mojtabanezhad Shariatpanahi ${ }^{1}$, Parisa Rokni ${ }^{1,2}$, Elaheh Shahabi ${ }^{1,3}$, Fatemeh Varshoee Tabrizi ${ }^{1}$ \\ and Mohammad Amin Kerachian 1,4,5*
}

\begin{abstract}
Objective: In the present study, we investigated different simple and cost effective methods to evaluate and validate cell free DNA (cfDNA) isolation. The ability of the QIAamp DNA Blood Mini Kit method to extract cfDNA was assessed by several approaches, including purification of endogenous cfDNA and exogenous spike-in control material, prior to plasma extraction, and followed by quantitative-PCR.

Results: Using QIAamp DNA Blood Mini kit, nearly 27\% (380 bp) to 35\% (173 bp) cfDNA was recovered with a higher recovery of smaller size cfDNA (173 bp) in comparison to larger ones (380 bp). These simple laboratory methods can be used to assess the efficiency of any cfDNA isolation method.
\end{abstract}

Keywords: Plasma, Liquid biopsy, Cell-free DNA

\section{Introduction}

Circulating cell-free DNA (cfDNA) molecules are shed into bloodstream, plasma, serum, urine as well as other body fluids of humans [1]. Most evidence suggests that the released cfDNA is primarily a consequence of apoptosis that could be released by various pathologic and normal physiologic mechanisms [2]. Evaluation and quantification of cfDNA in plasma or serum, termed "liquid biopsy" has become one of the most important clinical analysis for early cancer detection, genetic and epigenetic monitoring, recurrence prediction, therapeutic resistance assessment of cancer and prenatal testing [1-3]. Comprehensive liquid biopsy analysis may also represent a tool to assess both tumor burden and molecular features of disease [4]. Despite the extensive clinical utility of cfDNA, there are some challenges and difficulties in its extraction and subsequently its usage for example cfDNA is mostly fragmented and exists at very low

*Correspondence: amin.kerachian@mail.mcgill.ca;

kerachianma@mums.ac.ir

${ }^{5}$ Department of Medical Genetics, Faculty of Medicine, Mashhad University of Medical Sciences, Mashhad, Iran

Full list of author information is available at the end of the article concentrations in plasma. Isolation, quantification and evaluation of cfDNA is not a straightforward task and it requires a sensitive and reliable workflow. Therefore, the present study designed and performed different simple experiments to isolate cfDNA and validate the extraction.

\section{Main text}

\section{Sample collection and preparation}

Plasma samples were chosen for evaluation of cfDNA extraction since the extracted cfDNA from plasma contains a lower background concentration of wild-type DNA in comparison to serum [2]. Peripheral blood was collected from healthy volunteers, placed into EDTA tubes and kept at room temperature $\left(18{ }^{\circ} \mathrm{C}-22{ }^{\circ} \mathrm{C}\right)$ for no more than $2 \mathrm{~h}$. Thereafter, the blood sample was centrifuged twice at $800 \mathrm{~g}$ for $10 \mathrm{~min}$ followed by $1600 \mathrm{~g}$ for $10 \mathrm{~min}$. The plasma was separated and transferred to another tube and stored at $-80^{\circ} \mathrm{C}$ for further analysis.

\section{Circulating cell-free DNA extraction}

Plasma samples were thawed prior to Qiagen extraction. In accordance with the manufacturer's instructions, DNA was purified using the QIAamp Blood DNA Mini Kit (Qiagen, UK) by fast spin-column procedures. The 
protocol was performed by using $300 \mu \mathrm{l}$ plasma and eluting the DNA with $30 \mu \mathrm{l}$ of elution buffer (AE) in 2 steps, with $20 \mu \mathrm{l}$ and $10 \mu \mathrm{l} \mathrm{AE}$ and incubation time of $5 \mathrm{~min}$ each.

\section{Experiment 1: following the spiked 100 base-pair DNA ladder}

To evaluate the bias associated with fragment size, and to determine if the DNA extraction method has led to loss of small or large DNA fragments, the following approach was used. Plasma of a healthy human was prepared as previously described. Ten microliter of GeneRuler $100 \mathrm{bp}$ (Thermo-Scientific, United States) as a cfDNA was spiked in $300 \mu \mathrm{l}$ plasma sample. The extraction was performed and the purified DNAs were analyzed on a $2 \%$ UltraPure Agarose gel (Invitrogen, United States) stained by Green Viewer (Parstous Biotechnology Co., Iran).

\section{Experiment 2: looking for Y-chromosome-specific sequences in male-bearing pregnancy}

To ensure the presence of cfDNA in the extracted DNA, Y-chromosome-specific sequence (DYS221 locus), which represents male fetuses and does not exist in the maternal genome, was sought in male-bearing pregnancy in the maternal blood. Cell-free fetal DNA fraction represents approximately $3-13 \%$ of the total cell-free maternal DNA plasma. Since a median of $99 \%$ of the fetal-derived DNA molecules was less than 313 base pair (bp) in length [5], a 173 bp amplicon of DYS221 locus was considered for amplification.

One and a half milliliter of plasma obtained from a woman with male-bearing pregnancy was prepared. Pooled plasma was divided into 5 micro-tubes $(300 \mu \mathrm{l}$ in each), and then extractions were performed. All these samples were evaluated by SYBR-Green real-time PCR in triplicate. DNA plasmas from a non-pregnant female and a male were considered as negative and positive controls, respectively. The quantitative PCR (qPCR) assays were performed according to the MIQE guidelines.

PCR amplifications were carried out on a LightCycler ${ }^{\circledR}$ 96 System (Roche, Germany). PCR was carried out in a $15 \mu \mathrm{l}$ total volume using HiFi SYBR Green Master Mix (Farabin, Iran), $300 \mathrm{nM}$ of each primer (Additional file 1: Table S1) , and $2.5 \mu \mathrm{l}$ of DNA template. The amplification was consisted of $15 \mathrm{~min}$ at $95{ }^{\circ} \mathrm{C}$, followed by 50 cycles of $20 \mathrm{~s}$ at $95^{\circ} \mathrm{C}, 15 \mathrm{~s}$ at the primer annealing temperature of $59^{\circ} \mathrm{C}$ and $15 \mathrm{~s}$ at $72{ }^{\circ} \mathrm{C}$.

\section{Experiment 3: following spiked bisulfite DNA}

To assess the extraction efficiency, pooled plasma of a healthy human was divided into five micro-tubes $(300 \mu \mathrm{l}$ in each). EpiTect Control Unmethylated Bisulfite DNA (Qiagen, Germany) was spiked into all the plasmas, at a final concentration of $75 \mathrm{ng} / \mathrm{ml}$. Spiked bisulfite DNA was re-purified using QIAamp Blood DNA Mini kit extraction method.

Each sample was evaluated by SYBR-Green real-time PCR with bisulfite specific PCR (BSP) primers for Bone Morphogenic Protein 3 gene $\left(B M P_{3}, 256\right.$ bp) [6] in triplicate. BSP primers specifically amplify bisulfite converted DNA (Additional file 1: Table S1). Genomic DNA was used in qPCR as a negative control and bisulfite unmethylated DNA as a positive control. The qPCR assays were performed according to the MIQE guidelines.

Since a large fraction of DNA will be lost during bisulfite conversion, SYBR-Green nested qPCR assay was carried out [7]. PCR amplifications were run on a LightCycler $^{\circledR} 96$ System (Roche, Germany). PCR was carried out in a $15 \mu$ lotal volume using HiFi SYBR Green Master Mix (Farabin, Iran), $300 \mathrm{nM}$ of each primer, $0.2 \mu \mathrm{g} / \mu \mathrm{l}$ bovine serum albumin and $2.5 \mu \mathrm{l}$ of bisulfitemodified template. The amplification was consisted of $15 \mathrm{~min}$ at $95^{\circ} \mathrm{C}$, followed by 15 cycles of $20 \mathrm{~s}$ at $95^{\circ} \mathrm{C}, 15 \mathrm{~s}$ at the primer annealing temperature of $60^{\circ} \mathrm{C}$ and $15 \mathrm{~s}$ at $72{ }^{\circ} \mathrm{C}$.

For the second round of amplification, $2 \mu \mathrm{l}$ of the PCR product from the initial amplification was used as the template. The condition of second round qPCR was $15 \mathrm{~min}$ at $95{ }^{\circ} \mathrm{C}$, followed by 40 cycles of $20 \mathrm{~s}$ at $95^{\circ} \mathrm{C}$, $15 \mathrm{~s}$ at the primer annealing temperature of $60^{\circ} \mathrm{C}$ and 15 s at $72{ }^{\circ} \mathrm{C}$.

\section{Experiment 4: following spiked male genomic DNA}

To measure the absolute quantification of cfDNA extracted by Qiagen method, pooled plasma of healthy woman was divided in 11 microtubes $(300 \mu \mathrm{l}$ in each). Fragmented male genomic blood DNA was spiked at $1600 \mathrm{ng} / \mathrm{ml}(1.6 \mathrm{ng} / \mu \mathrm{l})$ as final concentration in each plasma (10 microtubes). One remaining unspiked microtube was used as a negative control. To assess the recovery of the exogenous spike-in from cfDNA extraction, a seven-point two-fold dilution series (from $0.25 \mathrm{ng} / \mu \mathrm{l}$ to $16 \mathrm{ng} / \mu \mathrm{l}$ ) of the genomic DNA from male blood (diluent, nuclease-free water) was used to draw standard curve for Y-chromosome-specific sequences: DYS221 locus (173 bp) and $D A Z$ locus (380 bp) separately (Additional file 1: Table S1).

All samples were evaluated by SYBR-Green qPCR in triplicate and the mean value was used for quantification. Its efficiency was calculated based on the slope of the standard curve (equation: efficiency $\left.=\left(10^{(-1 / \text { slope })}-1\right) \times 100\right)$ and all correlation coefficients $\left(r^{2}\right) \geq 0.99$ were considered. Melting curves of all samples were observed carefully to ensure that only one product was amplified. The qPCR assays were performed according to the $M I Q E$ guidelines. 


\section{Experiment 5: Kras mutation monitoring}

To show the presence of cell-free tumor DNA in cfDNA extractions, Kras mutation analysis was performed on the extracted cfDNA from plasma of a Kras positive colorectal cancer patient (exon 2, codons 12, G12D mutation).

Mutation detection was performed with a clinical validated approach based on the allele-specific qPCR intplex method [8]. PCR cycling analysis was conducted on LightCycler ${ }^{\circledR} 96$ Real-Time PCR System.

Design of $\mathrm{qPCR}$ primer systems were such that it could amplify two amplicons within a region of the target mutant: one corresponding to a mutated allele specific amplicon (61 bp, melting temperature about $81{ }^{\circ} \mathrm{C}$ ) and the other to a wild-type reference amplicon $(67 \mathrm{bp}$, melting temperature: about $75^{\circ} \mathrm{C}$ ). The test discriminates highly and specifically between mutant and wild-type alleles using a blocking 3 '-phosphate modified oligonucleotide and low Tm primers.

The PCR conditions for KRAS were as follows: each $15 \mu$-triplicate reaction contained $2 \mu \mathrm{l}$ of purified DNA diluted in 5X HOT FIREPol ${ }^{\circledR}$ EvaGreen ${ }^{\circledR}$ qPCR Mix Plus HRM Master Mix and $200 \mathrm{nM}$ primers (Additional file 1: Table S1), with the following PCR program and melting conditions used for all amplicons: $95{ }^{\circ} \mathrm{C}$ for $15 \mathrm{~min}$; 45 cycles of $95^{\circ} \mathrm{C}$ for $15 \mathrm{~s}$ and $60{ }^{\circ} \mathrm{C}$ for $20 \mathrm{~s} ; 90{ }^{\circ} \mathrm{C}$ for $30 \mathrm{~s}$, followed by a high resolution melt of $55-90{ }^{\circ} \mathrm{C}\left(0.01{ }^{\circ} \mathrm{C} / \mathrm{s}\right.$, 45 acquisitions $\left./{ }^{\circ} \mathrm{C}\right)$. Data were acquired and analyzed using the accompanying High Resolution Melt software $1.1 v$. All HRM reactions were run in triplicate.

Quantitative results were measured as mean \pm standard deviation (SD) and differences were assessed by two-tailed unpaired t-test. The reproducibility of different protocols was evaluated by coefficient of variation (CV). p-value less than 0.05 was considered statistically significant.

\section{Experiment 1: result}

After re-purification, the DNA ladder was analyzed on $2 \%$ UltraPure Agarose gels by Green Viewer as shown in Fig. 1. The figure displays that all sizes of DNA ladder were purified with Qiagen method similar to the ladder configuration.

\section{Experiment 2: result}

SYBR-Green qPCR were performed in triplicate for DYS221 locus (173 bp). Melting curves of all samples were observed for every reaction to ensure that only one product was amplified. Three out of 5 Qiagen (Cq mean: 35.1) samples were successfully amplified indicating the presence of cfDNA in extracted DNA in this method (Additional file 2: Fig. S1).

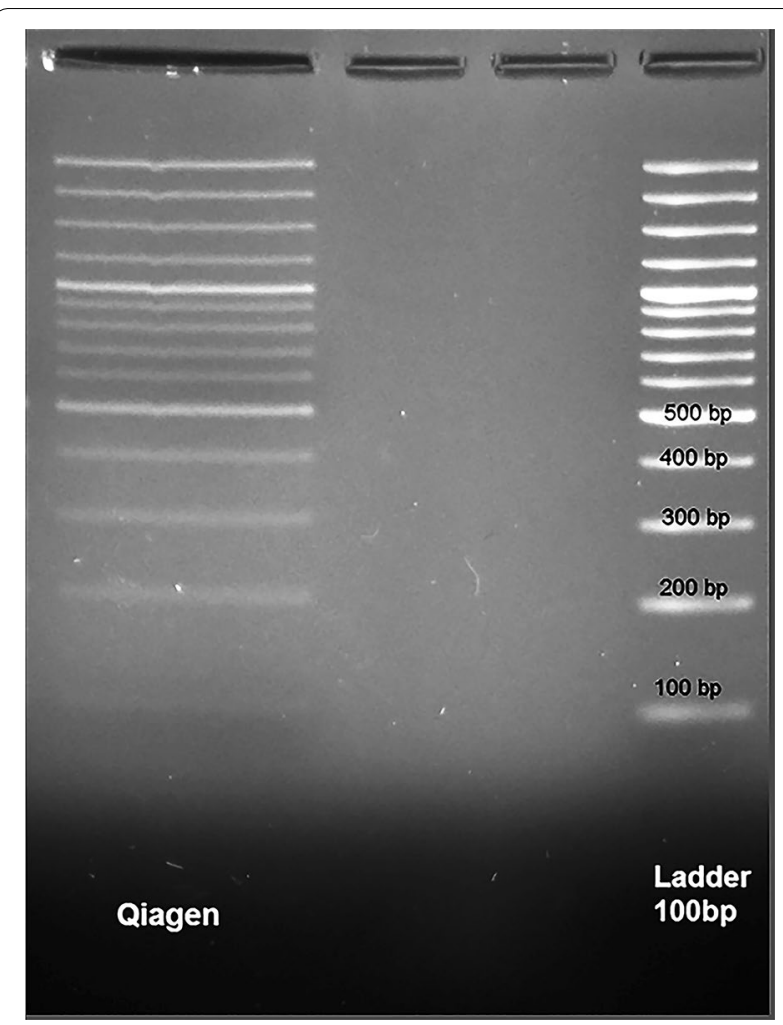

Fig. 1 The purified cfDNA analysis on a 2\% agarose gel

\section{Experiment 3: result}

SYBR-Green nested qPCR were performed in triplicate for $B M P_{3}(256 \mathrm{bp})$. Results showed that all Qiagen $(\mathrm{Cq}$ mean: 33.3 ) samples were successfully amplified by the SYBR-Green nested qPCR (Additional file 3: Fig. S2).

\section{Experiment 4: result}

CfDNA extraction for Qiagen method were performed in 10 replicates and each sample was quantified by SYBRGreen qPCR in triplicate for DAZ locus (380 bp) and DYS221 locus (173 bp) separately.

The standard curve of the DAZ and DYS221 amplicon showed a PCR efficiency of $100 \%$ and $94 \%$ respectively. The linear regression analysis of mean cycle threshold values per triplicate against $\log$ concentrations in the dilution yielded $\mathrm{R}^{2}=1$ for $D A Z$ and $\mathrm{R}^{2}=0.99$ for $D Y S 221$ locus (Additional file 4: Fig. S3).

All Qiagen samples were successfully amplified by the SYBR-Green $\mathrm{qPCR}$ assay. The mean $\pm \mathrm{SD}$ of Cq-value was 21.6 \pm 0.37 (range 21.0-22.1) for $D A Z$ locus and $24.2 \pm 0.26$ (range 23.9-24.6) for DYS221 locus. The mean \pm SD of concentration value was $4.54 \pm 1.25$ (range 3.1-6.75) for $D A Z$ locus and $5.85 \pm 0.93$ (range: $4.66-$ 7.14) for DYS221 locus. Data were presented as scatter 


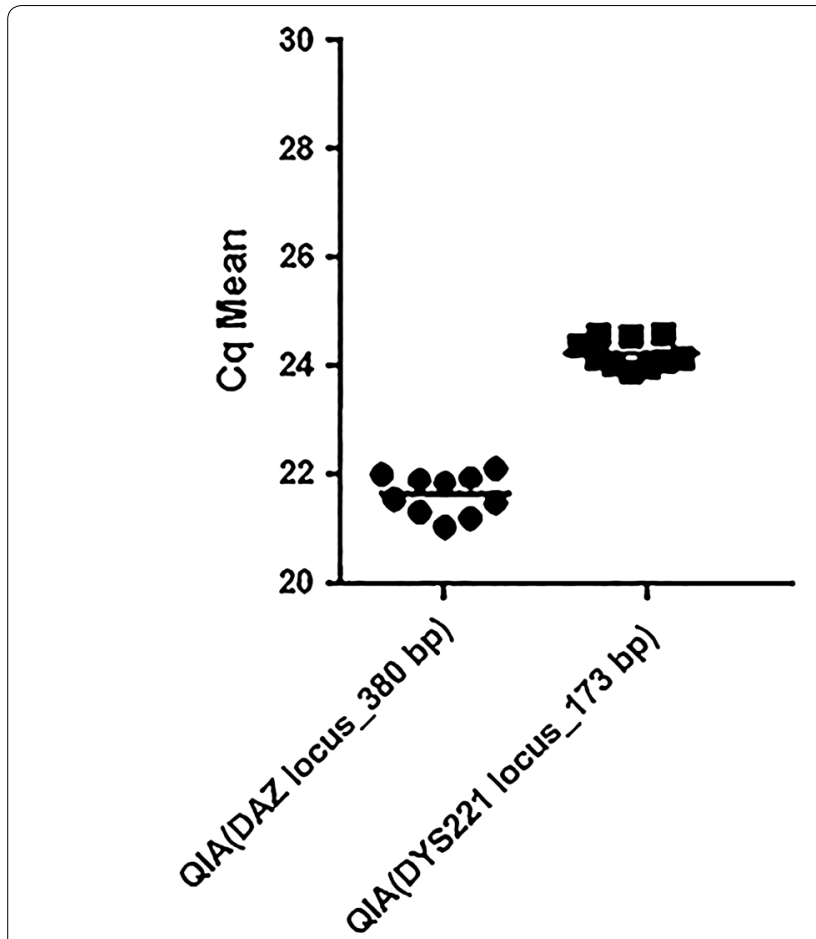

Fig. 2 Cq mean and concentration mean (ng/ $\mathrm{\mu l})$

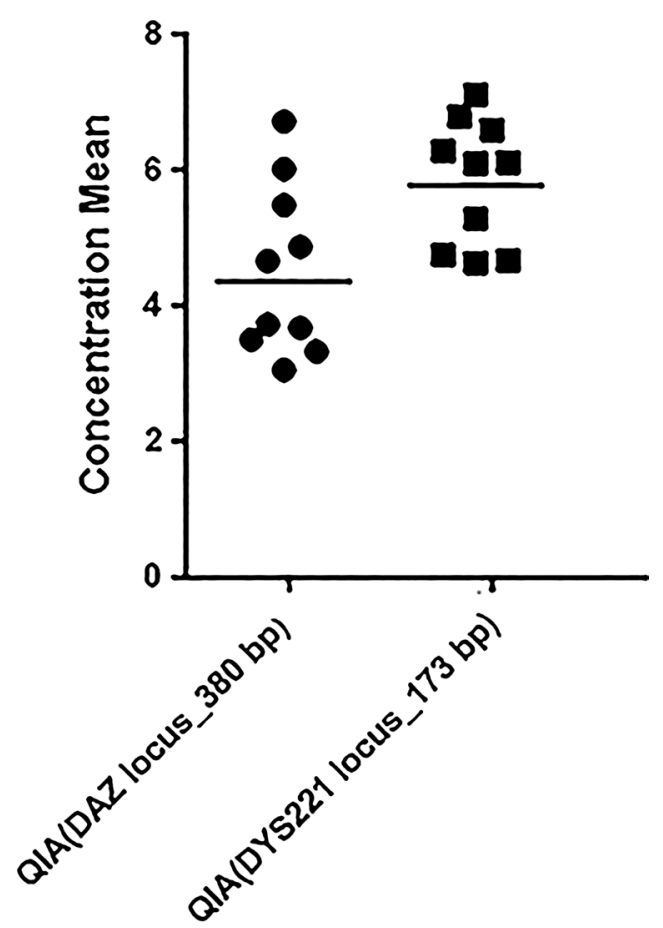

dot plot (Fig. 2). The Cq coefficients of variation (CV) was $1.74 \%$ for $D A Z$ and $1.07 \%$ for $D Y S 221$ locus and the concentration $C V$ was $27.56 \%$ and $15.89 \%$ for $D A Z$ and DYS221 locus, respectively.

Results showed that the recovery of Qiagen cfDNA extraction was about $27 \%$ for $D A Z$ locus and $35 \%$ for $D Y S 221$ locus and this kit had a CV of $15 \%, 26 \%$, for $D A Z$ and DYS221 loci, respectively.

\section{Experiment 5: result}

Results indicated that Kras mutation was detected in cfDNA extracted by Qiagen method in plasma of a colorectal cancer patient whose colon biopsy was already Kras positive (Fig. 3).

Sample handling and the techniques used for cfDNA analysis are one of the major hindrances in cfDNA studies $[9,10]$. Pre-analytical factors i.e. every step from

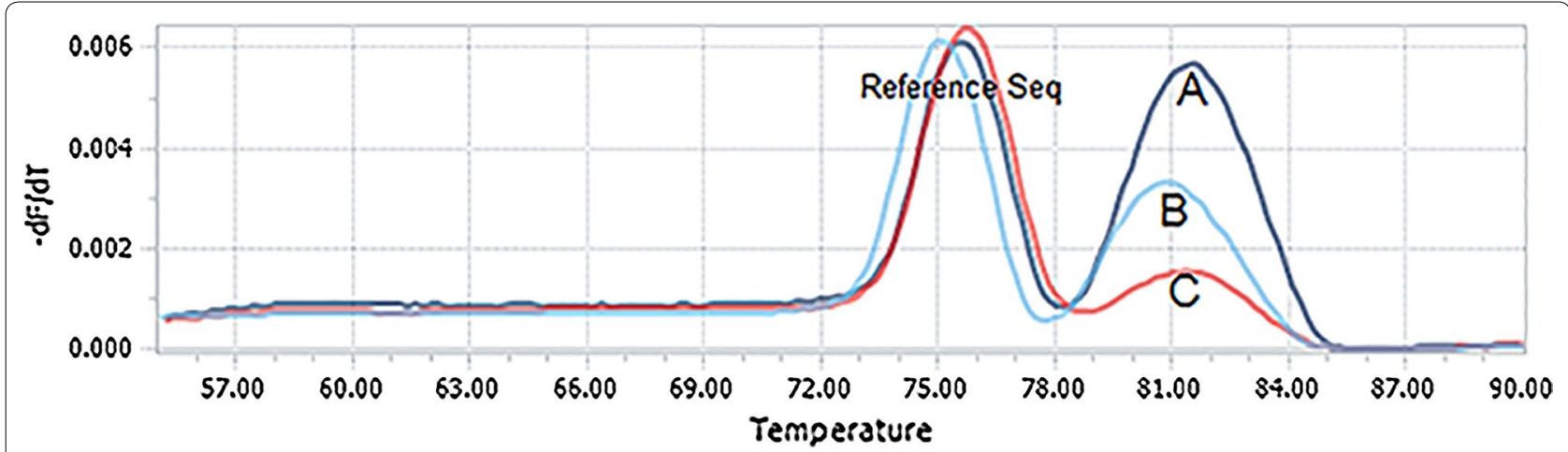

Fig. 3 Schematics of the methodology and the melting curve analysis of Kras (35G > A; G12D) point mutation detection (malting temperature: $81^{\circ} \mathrm{C}$ ). a Tissue of Kras positive colorectal cancer patient. b, c Plasma cfDNA extraction by Qiagen (duplicate) 
blood draw to sample collection and storage of DNA, potentially affecting cfDNA concentration and fragmentation, should be taken into account during data analysis $[9,11]$.

We demonstrated that using Qiagen kit, nearly $27 \%$ (DAZ, $380 \mathrm{bp)}$ to 35\% (DYS221, $173 \mathrm{bp)} \mathrm{cfDNA} \mathrm{was}$ recovered with a higher recovery for smaller size cfDNA (DYS221, $173 \mathrm{bp}$ ) in comparison to larger ones (DAZ, $380 \mathrm{bp}$ ). Xue et al. reported the efficiency of DNA extraction was $18.6 \%$ using the standard QIAamp Blood mini kit [12]. Fleischhacker et al. showed the median values for the quantitation for QIAamp DNA Blood Midi Kit was about $1.6-2.7 \mathrm{ng} / \mathrm{ml}$ [13].

\section{Limitation}

This study has some limitations. Studies with larger sample size, could have more robust and consistent results. The results of some experiments could be affected due to the very fragmented and low concentration of cfDNA in plasma. The cfDNA extracted from plasma is instable and could be degraded by the passage of time as experienced by many scientists.

\section{Additional files}

\section{Additional file 1: Table S1. Primer sequences.}

Additional file 2: Fig. S1. SYBR Green real-time PCR for DYS221 locus in male bearing pregnancy. (a) Amplification Curve. (b) Melting peak.

Additional file 3: Fig. S2. Amplification curve of BMP3 gene in following spiked bisulfite DNA experiment.

Additional file 4: Fig. S3. The standard curve of the DAZ and DYS221 amplicon.

\section{Abbreviations}

cfDNA: cell free DNA; bp: base pair; AE: elution buffer; qPCR: quantitative polymerase chain reactions; BSP: bisulfite specific polymerase chain reactions; SD: standard deviation; CV: coefficient of variation.

\section{Authors' contributions}

AMS and MAK conceived and designed the study. AMS, MAK and PR drafted the study protocol. FVT and MAK organized and supervised the study implementations, and AMS, MAK and PR drafted the manuscript. AMS, PR and ES performed the experiments and conducted the statistical analyses. AMS and MAK interpreted the results. All authors read and approved the final manuscript.

\footnotetext{
Author details

${ }^{1}$ Cancer Genetics Research Unit, Reza Radiotherapy and Oncology Center, Mashhad, Iran. ${ }^{2}$ Department of Medical Genetic, Tabriz University of Medical Sciences, Tabriz, Iran. ${ }^{3}$ Department of Biology, Faculty of Science, University of Guilan, Rasht, Iran. ${ }^{4}$ Medical Genetics Research Center, Mashhad University of Medical Sciences, Mashhad, Iran. ${ }^{5}$ Department of Medical Genetics, Faculty of Medicine, Mashhad University of Medical Sciences, Mashhad, Iran.
}

\section{Acknowledgements}

Our sincere thanks go to Reza Radiotherapy and Oncology Center (RROC) and also to Mr. Ebrahim Pouladin and Ms. Nafiseh Shalchi for their support in CRC research programs. We also give our special thanks to Ms. Maryam Yassi, Ms. Fatemeh Khadangi, Ms. Nosrat Nakhaie, and the staff of chemotherapy unit at RROC for their cooperation in this study.

\section{Competing interests}

The authors declare that they have no competing interests.

\section{Availability of data and materials \\ Not applicable.}

\section{Consent for publication}

Not applicable.

\section{Ethics approval and consent to participate}

All procedures performed in our studies involving human participants were in accordance with the ethical standards of the institutional and/or national research committee and has the approval from Mashhad University of Medical Sciences (Grant No. 961272). Informed consents were obtained written from all individual participants included in this study.

\section{Funding}

This research was conducted by the generous support of Reza Radiotherapy and oncology Center and financial support from Mashhad University of Medical Sciences (Grant No. 961272).

\section{Publisher's Note}

Springer Nature remains neutral with regard to jurisdictional claims in published maps and institutional affiliations.

Received: 15 September 2018 Accepted: 17 October 2018

Published online: 23 October 2018

\section{References}

1. van der Vaart M, Pretorius PJ. The origin of circulating free DNA. Clin Chem. 2007;53(12):2215. https://doi.org/10.1373/clinchem.2007.092734.

2. Qin Z, Ljubimov VA, Zhou C, Tong Y, Liang J. Cell-free circulating tumor DNA in cancer. Chin J Cancer. 2016;35:36. https://doi.org/10.1186/s4088 0-016-0092-4.

3. Babayan A, Pantel K. Advances in liquid biopsy approaches for early detection and monitoring of cancer. Genome Med. 2018;10:21. https:// doi.org/10.1186/s13073-018-0533-6.

4. Rossi G, Mu Z, Rademaker AW, Austin LK, Strickland KS, Costa RLB, et al. Cell-free DNA and circulating tumor cells: comprehensive liquid biopsy analysis in advanced breast cancer. Clin Cancer Res. 2018;24(3):560-8. https://doi.org/10.1158/1078-0432.ccr-17-2092.

5. Chan KC, Zhang J, Hui AB, Wong N, Lau TK, Leung TN, et al. Size distributions of maternal and fetal DNA in maternal plasma. Clin Chem. 2004;50(1):88-92. https://doi.org/10.1373/clinchem.2003.024893.

6. Zou H, Harrington JJ, Shire AM, Rego RL, Wang L, Campbell ME, et al. Highly methylated genes in colorectal neoplasia: implications for screening. Cancer Epidemiol Biomarkers Prev. 2007;16(12):2686-96. https://doi. org/10.1158/1055-9965.epi-07-0518.

7. Munson K, Clark J, Lamparska-Kupsik K, Smith SS. Recovery of bisulfiteconverted genomic sequences in the methylation-sensitive QPCR. Nucleic Acids Res. 2007;35(9):2893-903. https://doi.org/10.1093/nar/ gkm055.

8. Hamzehzadeh L, Khadangi F, Ghayoor Karimiani E, Pasdar A, Kerachian MA. Common KRAS and NRAS gene mutations in sporadic colorectal cancer in Northeastern Iranian patients. Curr Probl Cancer. 2018. https:// doi.org/10.1016/j.currproblcancer.2018.05.001.

9. El Messaoudi S, Rolet F, Mouliere F, Thierry AR. Circulating cell free DNA: preanalytical considerations. Clin Chim Acta. 2013;424:222-30. https:// doi.org/10.1016/j.cca.2013.05.022.

10. Rokni P, Shariatpanahi AM, Sakhinia E, Kerachian MA. BMP3 promoter hypermethylation in plasma-derived cell-free DNA in colorectal cancer 
patients. Genes Genomics. 2018;40(4):423-8. https://doi.org/10.1007/ s13258-017-0644-2.

11. Elshimali YI, Khaddour H, Sarkissyan M, Wu Y, Vadgama JV. The clinical utilization of circulating cell free DNA (CCFDNA) in blood of cancer patients. Int J Mol Sci. 2013;14(9):18925-58. https://doi.org/10.3390/ijms 140918 925.

12. Xue X, Teare MD, Holen I, Zhu YM, Woll PJ. Optimizing the yield and utility of circulating cell-free DNA from plasma and serum. Clin Chim Acta. 2009:404(2):100-4. https://doi.org/10.1016/j.cca.2009.02.018.
13. Fleischhacker M, Schmidt B, Weickmann S, Fersching DM, Leszinski GS, Siegele B, et al. Methods for isolation of cell-free plasma DNA strongly affect DNA yield. Clin Chim Acta. 2011;412(23-24):2085-8. https://doi. org/10.1016/j.cca.2011.07.011.
Ready to submit your research? Choose BMC and benefit from:

- fast, convenient online submission

- thorough peer review by experienced researchers in your field

- rapid publication on acceptance

- support for research data, including large and complex data types

- gold Open Access which fosters wider collaboration and increased citations

- maximum visibility for your research: over $100 \mathrm{M}$ website views per year

At BMC, research is always in progress.

Learn more biomedcentral.com/submissions 